\title{
Corrigendum: Phytogenic feed additives as an alternative to antibiotic growth promoters in broiler chickens
}

\author{
Ganapathi Raj Murugesan ${ }^{1}$, Basharat Syed ${ }^{2}$, Sudipto Haldar ${ }^{3}$ and Chasity Pender ${ }^{1 *}$ \\ ${ }^{1}$ BIOMIN America Inc., San Antonio, TX, USA, ${ }^{2}$ BIOMIN Holding GmbH, Getzersdorf, Austria, ${ }^{3}$ Department of Animal Nutrition, \\ West Bengal University of Animal and Fishery Sciences, Kolkata, India
}

Keywords: digestibility, histomorphology, microbiota, performance, poultry

\section{A corrigendum on}

Phytogenic feed additives as an alternative to antibiotic growth promoters in broiler chickens by Murugesan GR, Syed B, Haldar S and Pender C. Front Vet Sci (2015) 2:21. doi: 10.3389/fvets.2015.00021

There is a typographical error in Table 2 of this article. Under the "Grower period (22-39 days)" section, the body weight gain for the PFA group should have the superscript "a," instead of "b," indicating that it is significantly different from the Control and AGP groups.

\section{OPEN ACCESS}

Edited and reviewed by: Michael Kogut, United States Department of Agriculture - Agricultural Research Service, USA

*Correspondence: Chasity Pender chasity.pender@biomin.net

Specialty section: This article was submitted to Veterinary Infectious Diseases, a section of the journal Frontiers in Veterinary Science

Received: 03 September 2015 Accepted: 04 September 2015 Published: 22 September 2015

Citation:

Murugesan GR, Syed B, Haldar S and Pender $C$ (2015) Corrigendum:

Phytogenic feed additives as an alternative to antibiotic growth promoters in broiler chickens. Front. Vet. Sci. 2:37. doi: 10.3389/fvets.2015.00037
Conflict of Interest Statement: The authors declare that the research was conducted in the absence of any commercial or financial relationships that could be construed as a potential conflict of interest.

Copyright (C) 2015 Murugesan, Syed, Haldar and Pender. This is an open-access article distributed under the terms of the Creative Commons Attribution License (CC BY). The use, distribution or reproduction in other forums is permitted, provided the original author(s) or licensor are credited and that the original publication in this journal is cited, in accordance with accepted academic practice. No use, distribution or reproduction is permitted which does not comply with these terms. 